\title{
The doctrine of reconciliation: Its meaning and implications for social life
}

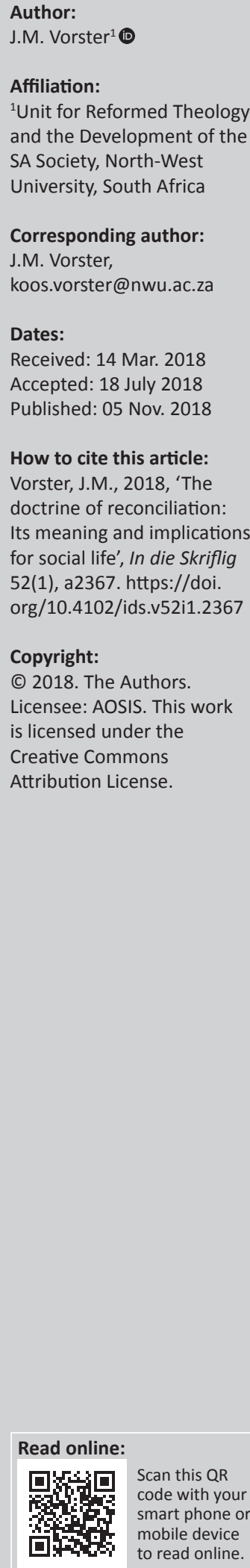

Reconciliation as a socio-political concept, has become highly topical in the South African discourse about social transformation over the past two decades in the aftermath of Apartheid. The idea of reconciliation emanates from the Christian tradition and is deeply embedded in Christian theology. For many centuries, the concept was dealt with as a merely theological concept belonging to the field of systematic theology and the pious, mystical and spiritual experience of Christians. Can this idea be transferred to the socio-political realm? The purpose of this article is to venture an answer to this question. The central theoretical argument is that the theology of reconciliation deals intrinsically with new relationships, and that these relationships have a concrete socio-political and ethical meaning. The aim is firstly, to investigate the idea as a theological concept from a classic reformed perspective and to ascertain whether the theological meaning can be transferred to the socio-political context as is done today in secular politics. The article concludes by stating that the doctrine of reconciliation, as seen from a classic reformed perspective, can be applied to all kinds of relations and has a deep bearing on the redressing of broken relationships and social cohesion. Reconciliation also has implications for eco-ethics.

\section{Introduction}

Reconciliation as a socio-political concept, has become a highly popular topic in the South African discourse about social transformation over the past two decades in the aftermath of Apartheid. The question discussed in fields within the humanities, social science and law is how to reconcile the racially divided South African society amidst continuing surges in racist behaviour and xenophobic upheavals. Moreover, what is the relationship between reconciliation and transformation, and the vestiges of inequality which require redress? Should transformation precede reconciliation as Mbeki (1998:70) argues? Furthermore, what will be the ends of a social reconciliation and what was the contribution of the Truth and Reconciliation Commission (TRC) in this regard (see Republic of South Africa 1998)? Must radical openness and the confession of truth be an absolute prerequisite for reconciliation? (Schreurs 2001:132). Last but not least: What is the role of Christians in South Africa in the quest for reconciliation according to the Christian tradition? Moral agents in the social and political spheres are struggling with these questions among others.

The idea of reconciliation emanates from the Christian tradition. For many centuries, the concept was dealt with as a merely theological concept belonging to the field of systematic theology and the pious, mystical and spiritual experience of Christians. In recent times, it became an ideal in the political realms of oppression, division and enmity, and the pursuance of nation building and new societies - as in the case of the post-Apartheid society. Reconciliation became just as much a socio-political concept as a theological concept. The purpose of this article is firstly, to investigate the idea as a theological concept from a classic reformed perspective and to ascertain whether the theological meaning can be translated into a socio-political context as is done today in secular politics. Secondly, the calling of Christians to introduce and promote reconciliation in the sociopolitical terrain in South Africa receives attention. The central theoretical argument is that the theology of reconciliation deals intrinsically with new relationships and that these relationships have a concrete socio-political and ethical meaning. Reconciliation, seen from a classic reformed perspective, can thus be applied to all kinds of relationships and has a deep bearing on the redressing of broken relationships and social cohesion.

\section{The theology of reconciliation}

The doctrine of reconciliation is deeply embedded in Christian theology (Sauter 2005:504). In the history of the church since Anselm of Canterbury (1033-1109), the concept has featured 
with different nuances. The essence was maintained, namely reconciliation by way of satisfaction. This doctrine teaches that the sacrifice of Christ averted the judgement of God upon sin and the revolt of humans against his holiness. Modern-day political theologies put the question of the social relevance of divine reconciliation on the table as a further exposition of this biblical doctrine. The doctrine of reconciliation is prominent in the New Testament, especially in the theology of Paul as indicated in the classic study of the Dutch theologian, Ridderbos (1971:197; see also De Gruchy 2002:51; Wolter 2015). Although the word reconciliation is used sparingly in the New Testament, the idea is inherently part of Paul's theology. Four passages are important for understanding Paul's thought about reconciliation. These are 2 Corinthians 5:18-21; Romans 5:8-11; Colossians 1:20-22 and Ephesians 2:14-17 (Porter 2016:121-122). The theological essence of the concept is expressed in 2 Corinthians 5 which reads:

Therefore, if anyone is in Christ, he/she is a new creation; the old has gone the new has come! All this is from God who reconciled us to himself through Christ and gave us the ministry of reconciliation: that God was reconciling to himself in Christ, not counting men's sins against them. And he has committed to us the message of reconciliation. We are therefore Christ's ambassadors, as though God were making his appeal through us. We implore you on Christ's behalf: Be reconciled to God! (vv. 17-21)

These verses can be regarded as the locus classicus of the doctrine of reconciliation. Several core characteristics of reconciliation emerge when the topic is addressed theologically.

Firstly, God and God alone takes the initiative for the reconciliation. God is the subject or agent of reconciliation (De Gruchy 2002:52). Due to the total depravity of humankind, humans are unable to build a new relationship with God or to renew creation. They have nothing to appease God. Welker (2013) says:

Only a truncated understanding of sin and a false understanding of atonement can suggest that human beings, in the midst of their enslavement to death, might yet be in a position to reconcile and appease God - for example through an offering of some sort. (p. 199)

Reconciliation is a gift from God founded on the promises enshrined in his universal covenant (see Browning \& Reed 2004:85; VanDrunen 2014:415). Although God in his common grace to all people bestows on people creational gifts such as a sense of morality and an ability to make just laws (natural law), these gifts cannot be used to satisfy the judgement of God in order to merit redemption from sin and brokenness. Real redemption, based on justification, is a gift from God in his particular grace to the people God has set aside as his people. However, this new covenant of grace reveals both the necessity and possibility of atonement. The covenant of grace in Christ opens a new source of gifts bestowed on the faithful by the Spirit of God (1 Cor 12). Most important of these is the sacrifice for atonement and the gift of faith by which Christ as the sacrifice can be grasped. Everything comes from God as an act of free grace. God provides the sacrifice necessary for atonement. God reconciles and humans are reconciled. It is solely an act of God executed by way of the priestly office of Christ which leads to the forgiveness of sins and a new life under the fulfilment and the guidance of the Spirit (see Jones 1995:66).

Secondly, reconciliation, as an act of God, has an eschatological character (Ridderbos 1971:198). The peace resulting from reconciliation is all about the removal of all the distortion brought about by evil. It indicates the eschatological reparation of all things. Reconciliation forms the foundation of a new creation. Therefore, Paul claims:

For God was pleased to have his fullness dwell in him and through him to reconcile to himself all things, whether things on earth or things in heaven, by making peace through his blood shed on the cross. (Col 1:19-20)

'All things' refer to the totality of cosmological restoration as they were before the fall. De Gruchy (2002) explains these texts as follows:

Not only humanity, but the whole created cosmos is included in God's act of reconciliation in Christ, thereby linking redemption and creation. In that remarkable opening chapter of Paul's letter to the Colossians 1:18-23, God's cosmic reconciling activity precedes and provides the framework within God's reconciliation of humanity occurs. (p. 53)

Reconciliation is thus linked to eschatology as well as history. Evil turns into good, enmity and hostility into peace, and hatred into love. It denotes a radical and all-encompassing transformation of everything that is realised in principle in this historical dispensation, and will reach its fullness and completeness with the coming of the new age introduced by the consummation in the second coming of Christ. Evil will be crushed under the feet of the God of peace (Rm 16:20). In this way, a new relationship will be constructed between God and the totality of creation. The expectation of the new dispensation as an emergent reality gives new meaning to the present and is the foundation of hope in the present life (see Moltmann 2012:91; Welker 2013:223). The promise of the eschatological reality is also the motivation of a moral lifestyle according to the principles of the kingdom of God revealed in Scripture. However, in essence the reconciliation is all about the renewal of all broken relationships.

Thirdly, reconciliation has thus a relational character. The new relationship between humans and God, due to the death and resurrection of Christ, is described in the Pauline corpus as justification (see Wolter 2015:138). Although the concepts justification and reconciliation in the Pauline theology can be seen as two perspectives on the one issue of redemption, each term has a specific focus and introduces a unique perspective. Justification is a juristic concept that indicates that the sinner has been pardoned from guilt due to the penitential exercise of Christ. According to Ridderbos (1971:197), the concept reconciliation is another way of expressing the new relationship between God and humans. Porter (2016:121) believes that the language of reconciliation owes its origins to the Hellenistic 
world. This idea can be questioned theologically, because while justification is a juristic term, reconciliation can be regarded a cultic term flowing from the Old Testament practices of worship. In the expiatory sacrifices of the Old Testament before the exile, God:

offered the possibility of approaching Him through sacrifices, which indicate the guilt of those who have forfeited their right to life but which also redeem them from the death they deserved. (Sauter 2005:504)

After the exile, Ezechiel mentions the practice of the sacrifice of reparation (Ez 40:39; 42:13; 44:29; 46:20; see De Vaux 1988:429).

These cultic acts denote the reparation of the relationship between God and humans. The idea of a sacrificial death was continued in the New Testament and applied to Christ as the final sacrifice (Heb 9:23-28). Theologically, reconciliation denotes the new relationship of the depraved human being with God on the foundation of the sacrifice of Christ on the cross. The act of reconciliation calls on people to refrain from their revolt against God and to turn to God with a new attitude. This is possible, because a new creation has come: '... the old has gone, the new has come' (2 Cor 5:17). The old is the dispensation of $\sin$, the brokenness of a distorted relationship with God and alienation. The new is the dispensation of the restored relationship with God, forgiveness of sins, the reign of Christ, the formation of the church and the powerful presence of the Spirit in the world. The act of reconciliation denotes a radical change in the human predicament and the possibility of a new life and new relationships. Reconciliation therefore has to do with the breaking down of the walls of enmity that separated Jews and Gentiles, men and women, masters and slaves and thereby creating the conditions on which harmonious relationships can be established (De Gruchy 2002:55). Galatians 3:28 which reads: 'There is neither Jew nor Greek, slave nor free, male or female, for you are all one in Christ', must therefore be regarded as the locus classicus of the description of the fruits of Christ's reconciling actions that spans all human divisions. Furthermore, the reconciled Christian is called to embrace the reconciliation actively. Reconciliation, as the expression of the new relationship, is juxtaposed to concepts such as enemies (Rm 5:10); barrier, the dividing wall of hostility (Eph 2:14) and is equated with peace (Rm 5:1, 10; Eph 2:15ff.; Col 1:10ff.).

Fourthly, reconciliation has a cosmological character which entails that the whole creational order is renewed by the sacrifice of Christ. The new order encompasses heaven and earth. God reconciles the totality of creation with himself (Ridderbos 1971:198). Everything is made subservient to the eternal reign of God. This reign is one for the better of all things. To say that God was reconciling the world in Christ is another way of saying that God was busy restoring God's reign of justice (De Gruchy 2002:54). The whole of creation becomes the kingdom of God which is realised in principle with the resurrection of Christ and which will come in its fullness and glory with the second coming of Christ. Evil forces cannot dissolve this reign of Christ. Evil may sometimes seem to have the upper hand, but will repeatedly be subjected by the reign of Christ. The reign of Christ determines the history of all people and the fate of nations. Furthermore, this reign with its eschatological and all-encompassing character, enables a new morality that can be searched for and realised in this world in the spirit of hope (Moltmann 2012:228).

Fifthly, reconciliation has to be ministered. Paul says:

And He has committed to us the message of reconciliation. We are therefore Christ's ambassadors, as though God were making his appeal through us. We implore you on Christ's behalf: be reconciled with God. (2 Cor 5:19-20)

This ministry coincides with the 'ministry of justification' and the 'ministry of the Spirit' (Ridderbos 1971:201). The reconciliation with God, which is initiated by God himself, must be grasped by faith of the merits of Christ. Reconciliation becomes a gift of grace to 'only those who are engrafted into Him and receive all His benefits, by a true faith' (Heidelberg Catechism 1563 Q \& A 20). The apostles were commissioned to testify to all the acts and the message of God's reconciliation, and especially to appeal to people to be reconciled with God by accepting this gift with true faith. In such a way - the only way - people can become part of the new creation - the creation under the reign of Christ (kingdom of God). Accepting the reconciliation entails to be reborn in the Spirit resulting in a new life with new relationships and morality. Faith in Christ results in a transfer from one sphere to another, and places a person in the church as the context for living the Christian life (Harvey 2012:79). 'For He rescued us from the domain of darkness, and transferred us to the Kingdom of his beloved son' (Col 1:13).

The question arises: Does this theological doctrine, as explained in these five points, have social-ethical relevance and if so, what is the socio-ethical relevance of the doctrine? One can assert that all Christian doctrines have ethical implications. Indeed, many other ethical directives will have a bearing on the issues at hand in this article. However, the focus here is on reconciliation which was, in the past, perceived as merely a concept in the spiritual domain. The same is true of reconciliation. Without diluting, the traditional theological meaning of reconciliation being a restoration of the relationship between God and humankind, it will be fair to say that reconciliation indicates, in essence, a renewal of all human relationships starting with the new relationship of the Christian with God. These relationships can be explained by way of the metaphor of concentric circles. The inner circle points to the new relation of the faithful to God. The second circle indicates the new relation between all the faithful in the formation of the church, in other words, the relation between Christians in the Christian community. This relationship is expressed in the Holy Communion. The third circle designates the renewed relationship of all people resulting in the quest for peace. The doctrine of reconciliation entails, inter alia, the search for peace with all people. The priestly 
office of the Christian stretches to everyone - also to the enemy. Furthermore, the doctrine summons us to promote peace with all, to love the enemy, to forgive and to do good to all people. Reconciliation brings about the promotion of peace and overcomes all forms of discrimination and oppression. The outer circle signifies the fourth new relationship, and that is the new relationship with creation. The distorted relationship of domination and exploitation, which results in environmental destruction, becomes a relationship of stewardship over God's creation. The next sections of the article deal with these implications, namely the formation of the church, the new relationship with humanity and the new relationship with creation.

\section{The formation of the church}

The new relationship of people with God and the peace it entails, resulted in the formation of the church which is, inter alia, described by the metaphor 'people of God'. This concept which originates in the Old Testament, was projected by the disciples of Christ to describe the new community that emerged from the act of reconciliation (Küng 1992:107). It is not the purpose of this article to explain all the metaphors used in the New Testament to described the church, but to outline the specific meaning of the church as a reconciled community. It is a community of equal people created in the image of God and which thus bridges all social barriers and divisions. It serves as an example of unity and love. This basic character of the church was touchingly described by Bosch (1991:172) as an alternative community in his reaction against the Apartheid theology in South Africa. As an alternative community, the church acts as a moral agent, in other words, as a community that can and should operate as an example of the fruit of the reconciliation on Christ. Moltmann (1990:122) entertains the same idea with his idea of the church as an Exodusgemeinde and a Kontrastgemeinschaft (see also Harvie 2009:34).

Hauerwas (1981:42) is to the point with his definition of the church as a community of character that should not have a social ethic, but should be a social ethic. The church should be in its way of life an example of moral conduct. As a reconciled community, it must show to the world what reconciliation means in its actual meaning. The new relationship with God and the fellow Christian, as expressed in the sacrament of the Holy Communion, must set an example for society at large. It must demonstrate the peace and love of God's act of reconciliation in Christ. When the church becomes the pawn of politics or secular ideologies, as happened in the past with for example the Apartheid theology and other political theologies, it fails to demonstrate true reconciliation. It then becomes an image of the broken society rather than an image of God's reconciled community.

Churches of the reformed tradition in South Africa (RCSA) are still struggling with the vestiges of Apartheid theology, especially with respect to inequality, racism and sexism. Although all local churches have been united in one synodical structure and claim to be multi-racial, they are still very much divided into churches with black people, mixed race people and white people as well as along linguistic lines. 'White' churches are in general more affluent than 'black' churches and this reality reflects the inequality of the South African society. 'White' churches tend to enter into the domain of mysticism and spirituality, while 'black' churches are more politically sensitive and aware of their calling in the public domain. The churches demonstrate more division than unity. In such a way, the testimony of the church as an alternative and exemplary community is diluted in this troubled country.

In this tradition, the true message of reconciliation is also impeded by discrimination based on gender. Women are, since 1973, not allowed to serve in the offices of minister or elder, irrespective of extensive studies in this regard (see Vorster 2016a; 2016b). The same kind of gender discrimination can be found in the Roman Catholic, Orthodox and certain Pentecostal traditions. In spite of the foundational guidance of Galatians 3:28 and the testimony of the history of revelation in Scripture about the equality of men and women, these traditions persist in gender discrimination with the argument of functional differentiation of gender roles. The question arises: What is the example set forward by these traditions? It can only be that women are inferior and subordinate, and not capable of serving in a ministerial role in the church. In South Africa, gender discrimination, especially the violation of the fundamental rights of women, is deeply embedded in African traditional religions and cultures (Nwachuku 1992:234). The example set by these Christian traditions is highly negative and impedes the liberation of women in society. If the church can discriminate against women with an appeal to Scripture, why should the fundamental rights of women be honoured in society? Furthermore, gender discrimination on religious grounds justifies the African patriarchal family structures with its disrespect for the fundamental rights of women and the girl-child. An example of reconciliation in the way of life of the church can have far-reaching effects and influences, but the contrary is also true. When the church sets an example of gender bias, subordination, patriarchy and disrespect for basic rights, the example of the church as an alternative community of reconciled peace-loving people is distorted. The example set by the church must be a mirror in which people can see a community without the destructive forces of racism, xenophobia, homophobia, ethnocentrism, gender discrimination and all other forms of social disintegration. The church should be a model of social cohesion that radiates all the values emanating from God's reconciliatory actions into society.

Besides being an example of an alternative reconciled community and as an ethic in itself, in the words of Hauerwas (1981:42), the church also has a prophetic and priestly role to play with regard to the promotion of peaceful relationships in society. The church must minister reconciliation (2 Cor $5: 18,19)$ and this message of reconciliation is the essence of the prophetic testimony of the church in the world. The gospel of reconciliation leads directly to defining the mission of the church in the world, namely to proclaim the gospel of reconciliation and the eschatological hope of God's 
restoration and renewal of the whole creation (De Gruchy 2002:55). All starts with the missional ministry of the church where all people are called upon to reconcile with God. The first words of the ministry should thus be in the words of 2 Corinthians 5:18 \& 19: 'Reconcile with God ...!' In such a way the most essential of all relationships will be restored, and that is the relationship with God in Christ. Without this restored relationship, all other relationships will be inoperative. Social reconciliation founds its deepest meaning in the reconciliation of the human with God by way of repentance, faith, conversion and forgiveness of sins. Reconciliation on the foundation of the life and example of Christ without repentance and faith is a mere social gospel and does not create a new humanity. Primarily, in the testimony and the mission of the church, is thus the prophetic calling of turning to God and acceptance of the sacrificial offering of Christ. The sacrament of the Holy Communion expresses this prophetic calling and its results. By breaking the bread and drinking the wine as the symbols of the body and blood of Christ, the faithful confess their new relationship with God in Christ. They are the body of Christ and calls upon humanity to repent and reconcile with God in a new mystical and spiritual union. This prophetic testimony of the church is founded on the Great Commission:

... go and make disciples of all nations, baptizing them in the name of the Father and the Son and the Holy Spirit, and teaching them to obey everything I have commanded you. (Mt 28:19)

To my mind, this essential aspect of the doctrine of reconciliation and its meaning for the mission of the church is neglected largely in modern-day public theologies with their emphasis on reconciliation as an idea only applicable to the social domain (see also Van de Beek 2005:517; 2012:137). Furthermore, the spiritual relationship of the church as a new community in Christ turns the church into a therapeutic community where all Christians become priests of healing and restoration (Vorster 2014:156). The priestly office of Christ flows into the priestly office of Christians. With reference to Calvin, Welker (2013:214) states that Christ intercedes on our behalf as chief priest before God, offering himself as a sacrifice and at the same time we are ourselves, in the power of the Spirit, priests in him. Just as he made reconciliation between God and humans a reality in the formation of the church as the new reconciled community, the faithful as priests have to accomplish reconciliation in the new community. The priestly role entails the healing of broken relationships within the new community. Here, broken relationships caused by divisions in the broader social life come to mind. It can be broken relationships between rich and poor, in the covenantal families or in any other form. When the faithful confess in the Holy Communion that they are one in Christ as his body, they simultaneously pick up the yoke of being a therapeutic community. Therefore, the church has to attend to the poor and the destitute, broken families, the sick and the suffering. To recapitulate: as a prophetic community, the church has to minister the reconciliation by calling all people to reconcile with God and to become part of the new community which is the body of Christ. As a priestly community, the church should act as a therapeutic community whose task it is to nurture the reconciliation amidst broken relationships and to unfurl the richness of the new relationships as a result of the reconciliation in Christ.

\section{The new relationship with humanity}

The reconciliation with God in Christ changes all other relationships that Christians have. In the above-mentioned section, the new relationship between Christians in the fellowship of believers in the church has been addressed briefly, but what about the relationships of Christians with people of other faiths and non-believers? The allencompassing effect of reconciliation also renovates these relationships. Christians are called upon to do good to all people and to love the enemy. They have to be the promotors of peace in society. As the 'salt of the earth' and the 'light of the world' they have to be agents in the formation of a new humanity. Seen from this angle, the doctrine of reconciliation has indeed social implications and public theologies are correct in their promotion of reconciliation in the public domain. Social reconciliation is an important effect of the biblical doctrine of reconciliation and therefore every theology has to be a public theology as Welker (2013:244) reminds us. Seen from the perspective of reconciliation, theology cannot be a reductionist theology concentrating solely on individual human beings and on their personal salvation.

As a reconciled community and a body of prophets and priests, the church has to promote love and peace in society. It should act as a watchdog in all processes of restoration of divided societies and of social cohesion. The same is true of Christians in society. Individual Christians, motivated by the reign of Christ and having been bestowed by the gifts of the Spirit, are all agents of reconciliation (see Vorster 2017b:24). They act as moral agents in many spheres such as politics, education, business, et cetera and in all of these they have to promote social cohesion and peace. They have to enhance the reconciliation they experience in the exemplary church and resonate the prophetic testimony of the church in this regard in all their spheres of life. Christians in South Africa are faced with this immense task.

Due to its colonial history, South Africa inherited a highly divided and unequal society. The society is plagued by racism, economic inequality, xenophobia, sexism and homophobia. Of these, racism is the most potent in destabilising peace and harmony. A long history of structural racism and social stratification brought forward a community still deeply divided on racial grounds and which suffers repeatedly the upheaval of unpleasant racial incidents. South Africa is well known for a history of racism. Since the establishment of a democratic government in 1994, various political administrations endeavoured to deal with racism. The most important was the work done by the TRC in 1998. However, racism did not end with the advent of democracy (Pillay 2014:144). Although the SAIRR (2016:2) 
reported recently on the basis of empirical scientific research that racial relations have improved in South Africa and that there are reasons for hope, the current rigorous debates on the issue - especially on social media - leaves the impression that racism is surging again. ${ }^{1}$ Boonzaaier (2010:86) argues that post-1994 South Africa still struggles with on-going racist behaviour. This enduring racism has also been accompanied by surges of violent xenophobia (Adjai \& Lazaridis 2013:255).

Holborn (2010) also concludes her research by stating that:

Overall, a general trend of a decrease in expressions of racial sentiment by decision-makers of the areas covered (in her research) can be detected from the material analysed. However this is not to suggest that the use of racial rhetoric by politicians is a thing of the past, or that inter-racial tensions have been overcome. (p. 155)

With reference to her research and many current discourses in the media, one may nevertheless ask: Have these trends worsened since 2010? Although recent developments especially during the Zuma-administration - have not been investigated in a valid scientific manner, it seems that incidents of racist behaviour have increased during his term of office, especially on social media (Harvey 2012). Scholars should be hesitant to promote extreme cases of racist behaviour perpetrated by radicals to the rule, but it seems that racist behaviour has risen to alarming levels. An alarming aspect of this trend is the way in which the previous State President, Jacob Zuma, used racial classifications in his propaganda before the 2016 local elections when he depicted white people as the enemy of progress and the reason for the poverty of African people.

Christians in South Africa should revive the reconciliation narrative regarding racism in the post-Zuma-era. In this process, Christians, as the custodians of reconciliation and human rights, should take the lead to put the honest debate about racism on track again in view of the upheaval of racism after the destructive Zuma-era in South Africa. As prophets and priests, Christians have to spell out what the reconciliation in Christ entails on the public domain regarding the perennial racist manifestations. Leaders should be sensitised not to play the racial card to conceal their own failures and selfish ideals. On the other hand, Christians in all lifestyles can promote an honest and open debate about the vestiges and harmful effects of racism, and the need to redress the injurious consequences with the aim of purposeful transformation. In the same way, the regular displays of xenophobia, tribalism, homophobia, sexism and other forms of discrimination should be dealt with. As people living in new relationships,

1.The SAIRR (2016:1) report says the following in this respect:

Social media in particular, have spoken of an 'unbridgeable gap' that has developed between Black and White South Africans. South Africans were said to 'have no interest in reconciliation, redress and nation-building'. The White community was alleged to be wracked with racism and filled with a deep desire to community was alleged to be wracked with racism and filled with a deep desire to bring back Apartheid. Black South Africans were said to be filled with hatred for The perception created was of a country on the verge of a race war.

2.In another study, I discuss the seminal research of Holborn (2010) more thoroughly within the context of the question whether racism in South Africa is at a tipping point (see Vorster 2017a). Herewith a brief reference to that study.
Christians motivated by the doctrine of reconciliation in Christ, cannot make peace with prejudice and inequity in their various forms in society at large.

\section{The new relationship with creation and stewardship}

Since the emergence of modernity with the development of natural sciences and industry, the role of humans in caring for creation was transformed into an attitude of exploitation and abuse. This exploitation led to what Broswimmer (2002:109) terms ecocide (the systematic destruction of the ecosystems). In his view, this process has a long history and took place in several phases. Today the ecological crisis is a proven fact and issues such as global warming is a muchdebated subject in virtually all scientific fields. Furthermore, the earlier much discussed article of White (1967) draws attention to the negative role of especially Christianity in the development of the ecological crisis. In his assessment of the theology of creation in Christianity, he maintains that God grants humans dominium over all creation. Eventually this dominion resulted in an 'anthropocentric religion' that was instrumental in the destruction of the ecosystems by various means. Loader (1987:9) also concludes that Christianity created a dualism between humankind and nature, and nature was relegated to something secondary. He maintains that Christianity does have a burden of blame to bear for what has happened with nature. Creation is seen as something for the use (and misuse) of humans. However, the perception of Christianity as an ecocidal and 'anthropocentric religion', does not represent the true meaning of human stewardship towards creation. The inclination to anthropocentrism is due to sin and should not be regarded as part of the creational order. It is a distortion of the relationship between humankind and creation as God intended it.

The first major factor revealed in the story of the creation is that humankind is an integral part of the creation. McCormick and Connors (2002:235) stress this important point in their application of biblical themes to environmental ethics. The Scripture reveals in Genesis 2 that humankind is part and parcel of the created order. Humankind was made from the same soil and clay God used to create the plants and the trees that cover the earth. Humans are not elevated above creation or called to function outside creation. As is explained in Job 38 and 39 and in Psalm 104, humankind exists alongside all God's other creatures. As part of creation, humankind depends solely on God for protection and care. These authors also refer to the doctrine of salvation in the New Testament where it is stated that it is not only humankind that will be redeemed through the sacrifice of Christ, but that the whole creation will be renewed or re-created. Paul wrote in Romans 8:21 that not only humankind, but also the rest of creation now sighs under its bondage to mortality, but will eventually be liberated from its bondage to decay and brought into the glorious freedom of the children of God. 
As an integral part of creation and because man is created in the image of God, God has given humankind the cultural mandate in Genesis 1:

God blessed them and said: 'Be fruitful and increase in number; fill the earth and subdue it. Rule over the fish of the sea and the birds of the air and over every living creature that moves on the ground. (v. 28)

This instruction is repeated in Genesis 2:15 when God put humankind in the Garden of Eden to work on it and take care of it. After the Fall in the story of Noah, God again commissioned humankind with the cultural mandate (Gn 9:1-3). Genesis uses strong language and the words used for 'subdue' and 'rule', give the impression of 'trample on'. That is why authors such as White accuses Christianity of being responsible for the ecological crisis today. Whereas other pantheistic religions deify nature, it seems that Christianity elevates humankind to rule over nature. However, such a conclusion is not valid, because the commission to rule implies service. The word culture stems from the Latin 'colere' which means 'to build' and 'to care' for. The Christian concept of ruling is to serve well (Geisler 2010:302). Christians are servants and not rulers. In this process, humankind is in service of God, like Christ who ruled by serving (Mk 10:45; Phlp 2:5-8). Christians must imitate the servanthood of Christ.

By considering other biblical passages, it becomes clear that the cultural mandate must be carried into effect in a responsible way and that means that humans must care for creation. Cunanan (1995:15) refers to one of these important passages in his reflection on the relevance of the prophecy of Joel for environmental awareness. He concludes that this prophet outlined a seven-point programme for environmental-developmental awareness and action. These are:

- awareness of the ecological situation;

- a call to mourning, lamentation, repentance (change in value and lifestyles);

- organising people along environmental and spiritual concerns;

- a warning of impending judgement and destruction;

- restoration and renewal of the environment and society;

- defining people's participation and roles in the transformation of society;

- addressing the political, economic and social components of the ecological and development agenda.

In his analysis of biblical evidence, Moltmann (1993:29) also says that the biblical charge is a dietary commandment. Human beings and animals alike are to live from the fruits which the earth brings forth in the form of plants and trees. Humankind is taught to care for animals. Animal abuse is, from the Bible's viewpoint, an abomination. If your enemy's ox or donkey wanders off you have to take it back to him. The righteous person cares for the needs of his animals (Pr 12:10). He knows also that an animal must be able to rest on the Sabbath (Ex 20:10; 23:12), and that a threshing ox may not be muzzled (Dt 25:4). Israel was also not permitted to do whatever she wanted to the trees, because when she besieged an enemy's town, she was not allowed to destroy the groves around the town (Douma 1996:209). God says, 'Are the trees of the field people, that you should besiege them?' (Dt 20:19 NIV). In the seventh year also the land should rest (Dt 23:10).

The sixth commandment has an environmental aim. Considering the synecdochal character of the Ten Commandments, it is fair to say that this commandment prohibits more than taking human life. It commands respect for all life created by God - the life of humankind, animal and plant. Human dominion must correspond with the care the Creator has for his creation and especially for every living creature. It is fair to say that the destruction of nature is seen in the Bible as humankind's revolt against God. Therefore, the imperative of lamentation, repentance and conversion implies not only a restoration of the relationship with God and fellowmen, but also with creation.

In conclusion, the concept cultural mandate, as embodied in the full biblical context, entails that humankind has the privilege to utilise creation for its own good, but that humans have the responsibility to take good care of everything God has created. The execution of the cultural mandate is subject to many other biblical norms. Humankind has to rule in harmony and not in hostility. Moltmann (1993:29) indicates that humankind's rule has nothing to do with the 'dominium terrae'. Humankind may use creation for its own survival, but humans have the calling to care for creation as God's stewards. In fulfilling its calling, humankind is responsible to God himself. Use may never become abuse. Therefore, to interpret Genesis 2:15 and 9:1-13 without the context of the whole biblical revelation may indeed lead to the erroneous conclusion that the cultural mandate implies dominion without responsibility. Such an interpretation is a distortion of the Christian message regarding the divine calling to care for the environment.

While sin distorted the calling of humans to be stewards, the reconciliation in Christ restores the relationship humans should have with creation. Therefore, the doctrine of reconciliation has a deep influence on the Christian calling to care for all living things as well as all sources such as air and water sustaining life. Christ restores the cultural mandate as it was meant to be in the creational order. Christians must carry this mandate into effect because of the reconciliation in Christ.

\section{Conclusion}

The doctrine of reconciliation is deeply embedded in Christian theology. Christ brought about reconciliation and atonement by way of his expiation as an answer to the judgement of God over sin and evil. This reconciliation entails:

- A new relationship between God and humankind that becomes visible in the formation of the church and the 
Holy Communion. The church is a reconciled community which has to, by way of being an exemplary community, display unity, peace and love. The church is a new community that overarches all human divisions such as racism and sexism. However, seen in the perspective of reconciliation, theology cannot be a reductionist theology concentrating solely on individual human beings and on their personal salvation. Reconciliation in Christ is not only a mystical characteristic, but has direct social implications.

- Therefore, reconciliation depicts the renewal of all other relationships. Christians live in a new relationship with the 'other' and has to realise these new relationships in their prophetic testimony and priestly deeds in society. They have to be the custodians in the formation of true humanity by promoting reconciliation between all people in society.

- Reconciliation in Christ also restores human relationships with creation. Instead of exploitation and misuse, Christians must fulfil the creational cultural mandate. As reconciled people, they have to be the proponents of ecological concerns and the precursors of the restoration of the integrity of creation.

\section{Acknowledgements}

This work is based on research supported by the National Research Foundation (NRF). Any opinion, finding and conclusion or recommendation expressed in this material is that of the author and the NRF does not accept any responsibility in this regard.

\section{Competing interests}

The author declares that he has no financial or personal relationships which may have inappropriately influenced him in writing this article.

\section{References}

Adjai, C. \& Lazaridis, G., 2013, 'People, state and civic responses to immigration, xenophobia and racism in the new South Africa', International Migration and Integration 15(1), 237-255

Boonzaaier, E.A., 2010, 'Racist accusation in contemporary South Africa: Lessons from studies of witchcraft', Anthropology Southern Africa 33(3 \& 4), 86-92. https://doi. org/10.1080/23323256.2010.11499997

Bosch, D.J., 1991, Transforming mission, paradigm shifts in the theology of mission, Maryknoll, New York.

Broswimmer, F.J., 2002, Ecocide: A short history of the mass extinction of species, Pluto Press, London.

Browning, R.L. \& Reed, R.A., 2004, Forgiveness, reconciliation and moral courage: Motives and designs for ministry in a troubled world, Eerdmans, Grand Rapids, MI.

Cunanan, J.P.M., 1995, 'The prophet of environment and development,' in D.G. Hallmann (ed.), Ecotheology, voices from South and North, pp. 9-20, Orbis Books, New York.

De Gruchy, J.W., 2002, Reconciliation: Restoring justice, Fortress Press, Minneapolis, MN.

De Vaux, R., 1988, Ancient Israel: Its life and institutions, transl. J. McHugh, Darton Longman \& Todd, London.
Douma, J., 1996, The Ten Commandments: Manual for the Christian life, P\&R Publishers, Phillipsburg.

Geisler, N.L., 2010, Christian ethics, options and issues, Baker Book House, Grand Rapids, MI.

Harvey, J.D., 2012, Interpreting the Pauline letters: An exegetical handbook, Krege Academic, Grand Rapids, MI.

Harvie, T., 2009, Jürgen Moltmann's ethics of hope: Eschatological possibilities for moral action, Ashgate, Farnham.

Hauerwas, S., 1981, A community of character: Towards a constructive, Christian social ethic, Notre Dame, London.

Heidelberg Catechism, 1563, in Beeke, J. \& Ferguson, S.B., 1999, Reformed confessions harmonized with an annotated bibliography of Reformed doctrinal works, Baker Books, Grand Rapids, MI.

Holborn, L., 2010, The long shadow of Apartheid, race in South Africa since 1994, South African Institute of Race Relations, Johannesburg.

Jones, L.G., 1995, Embodying forgiveness: A theological analysis, Eerdmans, Grand Rapids, MI.

Küng, H., 1992, The church, Burns \& Oates, Kent.

Loader, J.A., 1987, 'Image and order: Old Testament perspectives on the ecological crisis', in W.S. Vorster (ed.), Are we killing God's earth? Ecology and theology, pp. 1-15, University of South Africa, Pretoria.

Mbeki, T., 1998, Africa - The time has come, Tafelberg, Mafube, Cape Town.

McCormick, P. \& Connors, R.B., 2002, Facing ethical issues, dimensions of character, choices and community, Paulist Press, New York.

Moltmann, J., 1990, The way of Jesus Christ: Christology in messianic dimension, SCM Press, London.

Moltmann, J., 1993, God in creation, Fortress Press, Minneapolis, MN.

Moltmann, J., 2012, Ethics of hope, SCM Press, London.

Nwachuku, D.N., 1992, 'Women in Africa in the process of adjustment and change', Evangelical Review of Theology 16(3), 232-250.

Pillay, J., 2014, 'Has democracy led to the demise of racism in South Africa? A search for the answer in Gauteng schools', Africa Education Review 11(2), 146-163. https://doi.org/10.1080/18146627.2014.927147

Porter, S.E., 2016, The apostle Paul, his life, thought, and letters, Eerdmans, Michigan.

Republic of South Africa, 1998, Truth and Reconciliation Commission of South Africa Report, Juta, Cape Town.

Ridderbos, H., 1971, Paulus: Ontwerp van zijn Theologie, Kok, Kampen.

SAIRR, see South African Institute of Race Relations.

Sauter, G., 2005, 'Reconciliation', in E. Fahlbusch, J.M. Lochman, J. Mbiti, J. Pelikan \& L. Vischer (eds.), The Encyclopedia of Christianity, vol. 4, pp. 504-506, Brill, Leiden.

Schreurs, N., 2001, 'Truth and reconciliation: Is radical openness a condition for reconciliation?', in A. McFayden \& M. Scott (eds.), Forgiveness and Truth: Explorations in Contemporary Theology, pp. 131-138, T\&T Clark, Edinburgh.

South African Institute of Race Relations, 2016, Race relations in South Africa, reasons for hope, South African Institute of Race Relations, Johannesburg.

Van de Beek, A., 2005, 'Religion without ulterior motive', HTS Theological Studies 61(1 \& 2), 517-529. https://doi.org/10.4102/hts.v61i1/2.425

Van de Beek, A., 2012, Lichaam en geest van Christus: De theologie van die kerk en de Heilige Geest, Meinema, Zoetermeer.

VanDrunen, D., 2014, Divine covenants and moral order: A biblical theology of natural law, Eerdmans, Grand Rapids, MI.

Vorster, J.M., 2014, Christelike etiek in 'n sekulariserende samelewing, AOSIS, Cape Town. https://doi.org/10.4202/aosis.ceiss.2014.01

Vorster, J.M., 2016a, 'Die Gereformeerde kerke in Suid-Afrika en "vroue in die amp" 1973-1988', Studia Historia Ecclesiasticae 42(2), 137-156.

Vorster, J.M., 2016b, 'Die Gereformeerde kerke in Suid-Afrika en "vroue in die amp" 1974-2016', Studia Historia Ecclesiasticae 42(3), 1-22.

Vorster, J.M., 2017a, 'Kingdom, church and civil society - A theological paradigm for civil action', in M. Welker, N. Koopman \& J.M. Vorster (eds.), Church and civil society - German and South African perspectives, pp. 15-32, Sun Media, society - Germ
Stellenbosch.

Vorster, J.M., 2017b, 'Racism in South Africa: Are we at a tipping point?', in J. du Rand, J. Vorster \& N. Vorster (eds.), Togetherness in South Africa: Religious perspectives on racism, xenophobia and economic inequality, pp. 59-78, AOSIS, Cape Town.

Welker, M., 2013, God the revealed: Christology, transl. D.W. Stott, Eerdmans, Grand Rapids, MI.

White, L., 1967, 'The historical roots of our ecological crisis', Science 155(3767), 1195-1210. https://doi.org/10.1126/science.155.3767.1203

Wolter, M., 2015, Paul: An outline of his theology, transl. R.L. Brawley, Baylor University Press, Waco, TX. 